\title{
Interactive Effect of Variety and Irradiation Dose on Postharvest Behaviour of Fruits of Two Plantain (Musa sp AAB) Varieties from the Green Stage to the Onset of Ripening
}

\author{
Daniel Osei Ofosu ${ }^{*}$, Francis Appiah², Bernard Banful² \\ ${ }^{1}$ Biotechnology and Nuclear Agriculture Research Institute, Ghana Atomic Energy Commission, Accra, Ghana \\ ${ }^{2}$ Department of Horticulture, Kwame Nkrumah University of Science and Technology, Kumasi, Ghana \\ Email: *danofosu@hotmail.com
}

How to cite this paper: Ofosu, D.O., Appiah, F. and Banful, B. (2020) Interactive Effect of Variety and Irradiation Dose on Postharvest Behaviour of Fruits of Two Plantain (Musa sp AAB) Varieties from the Green Stage to the Onset of Ripening. American Journal of Plant Sciences, 11, 372-381. https://doi.org/10.4236/ajps.2020.113027

Received: January 27, 2020

Accepted: March 21, 2020

Published: March 24, 2020

Copyright $\odot 2020$ by author(s) and Scientific Research Publishing Inc. This work is licensed under the Creative Commons Attribution International License (CC BY 4.0).

http://creativecommons.org/licenses/by/4.0/

\begin{abstract}
Controlling ethylene production and respiratory rate of climacteric fruits is reported to extend the shelf-life of those produce. The aim of this present research was to determine the effect of five (5) doses of gamma irradiation as an ethylene and respiration inhibitor on two (2) distinct varieties of plantain (Musa sp $\mathrm{AAB}$ ) up to the onset of ripening. The variety and irradiation dose applied had a significant interaction on the number of days to the onset of fruit ripening. The daily mean ethylene production for both varieties was lowest at $200 \mathrm{~Gy}$. Even though Apantu had a lower daily average as compared to Apem, it reached the onset of ripening relatively quicker than Apem. Irradiation caused a significant decrease in the respiratory rate of the plantains. Irrespective of the dose applied, the unirradiated usually had a significantly higher respiratory rate and the accompanying carbon dioxide production. Plantain varieties irradiated at $1000 \mathrm{~Gy}$ had the highest amount of total soluble solids contents $\left(10.7^{\circ} \mathrm{Brix}\right)$ significantly higher than the other stages of ripening yet similar to the plantain varieties irradiated at $600 \mathrm{~Gy}\left(10.6^{\circ} \mathrm{Brix}\right)$, $800 \mathrm{~Gy}\left(10.6^{\circ} \mathrm{Brix}\right)$ and the unirradiated (0 Gy) plantain varieties $\left(10.3^{\circ} \mathrm{Brix}\right)$. The lower levels of soluble solids may confer a better cooking quality as plantains would be less sweet and also less prone to textural breakdown when cooked.
\end{abstract}

\section{Keywords}

Plantain, Gamma Irradiation, Ethylene, Respiratory Rate, Ripening

\section{Introduction}

The basic distinguishing feature between climacteric fruits and non-climacteric 
fruits is the increased ethylene synthesis and respiration rate during ripening of climacteric fruits [1]. Several aspects of the role ethylene plays in the ripening of climacteric fruits have been widely studied and well established [2] [3] [4] [5].

The response of matured fruits to ethylene is known to vary widely and is very much dependent on crop species, exposure dosages, as well as environmental conditions [3] [6]. This directly means that the process of ripening varies in different fruits as far as the involvement of ethylene is concerned [3]. Since ethylene often promotes its own production in plants [7], controlling its levels is crucial in maintaining crop quality.

There are contrasting reports on the role respiration plays in the onset of ripening of climacteric fruits. While [8] and [9] found no increase in the respiration rate during the ripening of tomato fruit (Lycopersicon esculentum cv. Castelmart) and muskmelon respectively, it is widely held that ethylene-associated respiration peak is present at the onset of ripening [10] [11].

The control of fruit ripening and storage ability can be achieved through a reduction of ethylene production and respiration [12] [13]. The differences in the reactions of different fruit species, and sometimes cultivars, to ethylene call for more investigation into the different ways in ethylene inhibition can affect the maturation, ripening, and storage of different cultivars of fruits. This present research sought to determine the effect of gamma irradiation as an ethylene and respiration inhibitor on two distinct varieties of plantain (Musa sp AAB) up to the onset of ripening.

\section{Materials and Methods}

\subsection{Plantain Varieties}

Two varieties Apantu (Falsehorn plantain) and Apem (French type) were used for the study. The fruits were allowed to fill up to the commercial level preferred by farmers. Mature green (13 weeks after flowering) unripe plantains (Musa sp $\mathrm{AAB}$ ) were obtained directly from the farmers on the same day of harvest at Adawso in the Eastern Region of Ghana (Map 1). Samples were taken from the first six rows of the proximal and midsection of the bunch.

\subsection{Irradiation}

Irradiation of samples was carried using a Cobalt-60 source under ambient conditions at the Gamma Irradiation Facility (GIF) of the Radiation Technology Centre (RTC) in the Ghana Atomic Energy Commission (GAEC) at irradiation doses of $200 \mathrm{~Gy}, 400 \mathrm{~Gy}, 600 \mathrm{~Gy}, 800 \mathrm{~Gy}$ and $1000 \mathrm{~Gy}$ before storage. A control experiment was carried out where the fruits were not irradiated (designated as 0 Gy). The dose rate was $1.962 \mathrm{kGy} / \mathrm{hr}$ and ferrous sulphate (Fricke) dosimeter was used to measure absorbed dose.

\subsection{Determination of Peel and Pulp Colours Up to the Onset of Ripening}

A visual method (based on a modification of banana ripening chart developed 


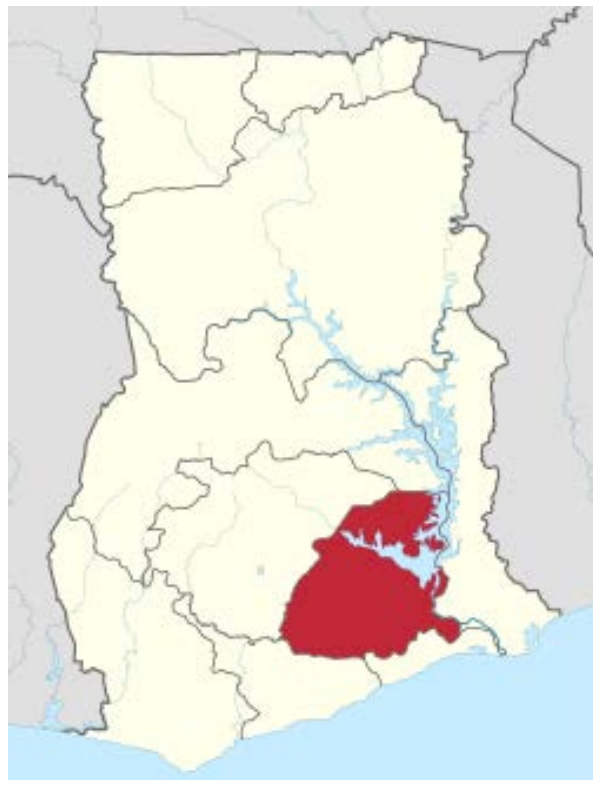

Map 1. Eastern region of Ghana.

by the [14]) was used to determine the peel colour. The scale was modified to end at the onset of ripening at ripening stage 4 or physiological stage 2 (Table $1)$.

\subsection{Determination of Amount of Ethylene Produced}

Ethylene production from the green mature stage (stage 1) to the onset of ripening (stage 4 ) was measured on a daily basis by enclosing whole fruit samples in an airtight container for one (1) hour at $25^{\circ} \mathrm{C}$, withdrawing $1 \mathrm{~mL}$ of the headspace gas, and injecting it into a gas chromatograph fitted with a pulse discharge helium ionization detector (PDHID, ethylene). The parameters of the gas chromatograph were: injector temperature $120^{\circ} \mathrm{C}$; detector temperature $200^{\circ} \mathrm{C}$; oven temperature $75^{\circ} \mathrm{C}$; sensitivity $4 \times 10$; carrier gas, Helium; flow rate through the column was $0.33 \mathrm{~mL} \cdot \mathrm{s}^{-1}$. Quantification of the amount of ethylene produced was according to the method of [7], in which 1-Aminocyclopropane-1-carboxylic acid (ACC) was quantitatively converted to ethylene and a standard curve for ethylene generated.

\subsection{Estimation of Amount of Carbon Dioxide Produced}

The respiratory rate (as carbon dioxide produced) from the green mature stage (stage 1) to the onset of ripening (stage 4) was measured using the method of [15] on a daily basis by enclosing whole fruit samples in an airtight container for one (1) hour at $25^{\circ} \mathrm{C}$, withdrawing $1 \mathrm{~mL}$ of the headspace gas, and injecting it into a gas chromatograph fitted with a thermal conductivity detector (TCD, $\mathrm{CO}_{2}$ ) and an activated alumina column. The parameters of the gas chromatograph were: injector temperature $120^{\circ} \mathrm{C}$; detector temperature $200^{\circ} \mathrm{C}$; oven temperature $75^{\circ} \mathrm{C}$; sensitivity $4 \times 10$; carrier gas, Helium; flow rate through the column was $0.33 \mathrm{~mL} \cdot \mathrm{s}^{-1}$. 
Table 1. Peel colour changes of plantain at various stages of ripening.

\begin{tabular}{lccc}
\hline Physiological phases & Ripening stage (colour score) & Description of peel colour \\
\hline Pre-climacteric & 1 & 1 & Green \\
& 1 & 2 & Pale green \\
& 2 & 3 & Pale green with yellow tips \\
Climacteric & 2 & 4 & $50 \%$ yellow 50\% green \\
& 2 & 5 & More yellow than green \\
& 2 & 6 & All yellow \\
& 3 & 7 & Yellow flecked with brown \\
Senescence & 3 & 8 & 50\% black 50\% yellow \\
& 3 & 9 & More black than yellow \\
& 3 & 10 & Pure black \\
\hline
\end{tabular}

\subsection{Determination of Starch Content Up to the Onset of Ripening}

The method of [16] was used. The samples were defatted with diethylether and the soluble sugars were removed with $80 \%$ ethanol at $80^{\circ} \mathrm{C}$. After centrifugation, the starch was hydrolyzed with $0.25 \mathrm{~mol} / \mathrm{L}$ sulfuric acid at $100^{\circ} \mathrm{C}$ for one (1) hour. The hydrolysate was mixed with $76 \%$ anthrone-sulfuric solution, heated for $10 \mathrm{~min}$ and cooled. A blank was prepared with distilled water instead of the sample extract. The absorbance was determined at $620 \mathrm{~nm}$ in a Shimadzu UV-vis 160 A spectrophotometer (Kyoto, Japan). The concentration of glucose was calculated from standard curves $(\mathrm{r} 2 \geq 0.9937)$ and the levels of starch $(\mathrm{g} / 100$ g) were calculated using a conversion factor of 0.9 .

\subsection{Determination of Reducing Sugar Content Up to the Onset of Ripening}

The reducing sugar content in the irradiated and unirradiated plantain pulp during the storage was determined using the Lane-Eynon method [17]. Ten (10) grams of the pulp was homogenized with $100 \mathrm{ml}$ of distilled water in a Waring Blender (Model 35BL59, USA) for 15 seconds. The homogenate was centrifuged at $4000 \mathrm{rpm}$ for five (5) minutes. Twenty-five (25) $\mathrm{ml}$ of mixed Fehling's solution was pipetted into $250 \mathrm{ml}$ volumetric flask. The flask was swirled while heating over a Bunsen flame. The mixed Fehling's solution was boiled moderately for 1.5 to 2 minutes and two (2) drops of methylene blue solution was quickly added. Immediately, the homogenate solution of the plantain was added via a burette at a rate of about $0.25 \mathrm{ml}$ per 15 seconds. The titration was completed within 3 minutes from the time boiling commenced.

$$
\text { Percentage of reducing sugars }(\text { calculated as sucrose })=\frac{100 \times A \times a}{P \times V}
$$

where $A=$ volume (mL) of solution of prepared sample; $P=$ weight of sample used $(\mathrm{g}) ; V=$ volume $(\mathrm{mL})$ of sample aqueous solution used in titration; $a=$ amount of sucrose equivalent to $20 \mathrm{~mL}$ Fehling's solution 


\subsection{Determination of Total Soluble Solids ( ${ }^{\circ}$ Brix) Content Up to the Onset of Ripening}

The method of [18] was used to determine the total soluble solids (TSS) of fruit at the first four stages of ripening. Approximately $30 \mathrm{~g}$ of plantain pulp was homogenized in $90 \mathrm{~mL}$ of distilled water for $2 \mathrm{~min}$ and filtered using Whatman No.1 filter paper. A single drop of the filtrate was placed on the prism of a refractometer with a degree brix range of $0 \%-32 \%$ and resolutions of $0.2^{\circ}$ Brix at $20^{\circ} \mathrm{C}$ with distilled water and readings for percentage TSS were expressed in degrees Brix $\left({ }^{\circ} \mathrm{Bx}\right)$. Recorded values were multiplied by three due to the dilution factor of the pulp, which is three times the amount of distilled water.

\subsection{Data Analysis}

The data generated from this research was subjected to analysis of variance using the Statistix 10 statistical software. Means were separated using Tukey's HSD with the level of significance set at 0.01 .

\section{Results and Discussion}

Several researchers have recommended the use of gamma irradiation as one of the ways to extend the shelf life of many agricultural produce. Apart from delaying ripening, gamma irradiation has been reported to eliminate pathogenic bacteria, disinfest fresh fruits and vegetables as a postharvest quarantine treatment, inhibit sprouting of bulbs and tubers, and reduce or eliminate microorganisms [19] [20] [21].

In the present study, there was significant variety $\mathrm{x}$ irradiation dose interactions for the number of days to the onset of fruit ripening (Table 2). Apem irradiated at $200 \mathrm{~Gy}$ and the unirradiated (0 Gy) Apem took the longest time to start ripening (5.7 days), significantly longer than the other treatment combinations but similar to Apantu irradiated at $200 \mathrm{~Gy}$ (5.1 days) and Apem irradiated at 600 Gy (4.8 days).

The time taken for the individual varieties to reach the onset of ripening is directly linked to the amount of ethylene produced after irradiation (Table 3). The daily mean ethylene production for both varieties was lowest at $200 \mathrm{~Gy}$. Even though Apantu had a lower daily average as compared to Apem, it reached the

Table 2. Effect of variety and irradiation dose on the number of days to onset of fruit ripening.

\begin{tabular}{cccccccc}
\hline \multicolumn{7}{c}{ Number of days to onset of ripening } \\
\hline \multirow{2}{*}{ Variety } & \multicolumn{9}{c}{ Irradiation dose (Gy) } & Mean \\
\cline { 2 - 7 } & 0 & 200 & 400 & 600 & 800 & 1000 & 4.3 \\
\hline Apantu & 4.1 & 5.1 & 4.4 & 4.8 & 3.8 & 3.4 & 4.9 \\
Apem & 5.7 & 5.7 & 4.6 & 4.8 & 4.0 & 4.7 & \\
Mean & 4.9 & 5.4 & 4.5 & 4.8 & 3.9 & 4.0 & \\
\hline
\end{tabular}

Tukey HSD (0.01): Variety $=0.25$; Irradiation dose $=0.57$; Variety $\times$ Irradiation dose $=0.90$. 
Table 3. Effect of variety and irradiation dose on ethylene production $\left(\mu \mathrm{l} \cdot \mathrm{kg}^{-1} \cdot \mathrm{hr}^{-1}\right)$.

\begin{tabular}{cccccccc}
\hline \multicolumn{7}{c}{ Ethylene Production $\left(\mu \mathrm{l} \cdot \mathrm{kg}^{-1} \cdot \mathrm{hr}^{-1}\right)$} \\
\cline { 1 - 6 } Variety & \multicolumn{7}{c}{ Irradiation dose (Gy) } \\
\cline { 2 - 6 } & 0 & 200 & 400 & 600 & 800 & 1000 & \multirow{2}{*}{ Mean } \\
\hline Apantu & 310.1 & 286.5 & 250.3 & 241.8 & 237.5 & 256.0 & 263.7 \\
Apem & 467.1 & 386.4 & 451.1 & 444.8 & 374.6 & 438.7 & 427.1 \\
Mean & 388.6 & 336.5 & 350.7 & 343.3 & 306.0 & 347.3 & \\
\hline
\end{tabular}

Tukey HSD (0.01): Variety $=10.60$; Irradiation dose $=23.02$; Variety $\times$ Irradiation dose $=36.44$.

onset of ripening relatively quicker than Apem. In the present study, the production of ethylene production is not inhibited, even by doses of $1000 \mathrm{~Gy}$. The irradiation does (200 Gy and $400 \mathrm{~Gy}$ ) appear to cause a momentary inhibition in the volumes of the ethylene released by causing a mutation in the ACC oxidase production, the rate limiting enzyme, resulting in some delay before the fruits reach the onset of ripening. It is apparent that at maturity, ethylene is released by the fruit resulting in the ripening process being initiated before the application of the irradiation. The higher doses (600 Gy, $800 \mathrm{~Gy}$ and $1000 \mathrm{~Gy}$ ) appear to be causing other physicochemical changes in the plantain fruits thereby causing the fruit to respond quicker by producing more ethylene in a relatively short time.

From the present study, it is obvious that irradiation is causing a significant decrease in the rate of respiration (Table 4). This is evident from the fact that irrespective of the dose applied, the unirradiated usually had a significantly higher respiratory rate and the accompanying carbon dioxide production. There was however no clear pattern to the effect of the irradiation doses on the carbon dioxide production. [22] Reported that respiration rates decrease with increasing irradiation doses due to reduced metabolic activities of irradiated samples.

[23] and [24] report that the ${ }^{\circ}$ Brix increases in plantain fruits after harvest till the fruit reaches the climacterium. The increase in the total soluble solids content of plantains as it ripens has been attributed to the increased activity of ripening related enzymes like $\alpha$ amylase, $\beta$ amylase and starch phosphorylase [25] [26] which cause the starches in the pulp to be broken down to sugars. Plantain varieties irradiated at $1000 \mathrm{~Gy}$ had the highest amount of total soluble solids contents $\left(10.7^{\circ} \mathrm{Brix}\right)$ significantly higher than the other stages of ripening yet similar to the plantain varieties irradiated at $600 \mathrm{~Gy}\left(10.6^{\circ} \mathrm{Brix}\right), 800 \mathrm{~Gy}$ $\left(10.6^{\circ} \mathrm{Brix}\right)$ and the unirradiated (0 Gy) plantain varieties. $\left(10.3^{\circ} \mathrm{Brix}\right)$ (Table 5$)$. The higher doses broke down the complex starches hence their higher soluble solids content. [27] suggested that lower levels of soluble solids may confer a better cooking quality as plantains would be less sweet and also less prone to textural breakdown when cooked.

Apantu irradiated at $200 \mathrm{~Gy}$ had the highest starch content $(81.1 \mathrm{~g} / 100 \mathrm{~g})$, significantly higher than the other treatment combinations yet similar to the unirradiated (0 Gy) Apantu (80.9 g/100 g) and the Apantu irradiated at $400 \mathrm{~Gy}(80.5$ $\mathrm{g} / 100 \mathrm{~g})$. The least starch content was recorded in Apem irradiated at $1000 \mathrm{~Gy}$ 
Table 4. Effect of variety and irradiation dose on carbon dioxide production $\left(\mathrm{ml} \mathrm{CO} \mathrm{kg}^{-1}\right.$ $\left.\mathrm{hr}^{-1}\right)$.

\begin{tabular}{cccccccc}
\hline \multicolumn{7}{c}{ Carbon dioxide production $\left(\mathrm{ml} \mathrm{CO}_{2} \mathrm{~kg}^{-1} \mathrm{hr}^{-1}\right)$} \\
\hline \multirow{7}{*}{ Variety } & \multicolumn{7}{c}{ Irradiation dose $(\mathrm{Gy})$} \\
\cline { 2 - 7 } & 0 & 200 & 400 & 600 & 800 & 1000 & Mean \\
\hline Apantu & 223.5 & 240.8 & 188.1 & 214.8 & 166.2 & 156.2 & 198.3 \\
Apem & 244.6 & 215.0 & 184.7 & 190.8 & 153.2 & 184.2 & 195.4 \\
Mean & 234.0 & 227.9 & 186.4 & 202.8 & 159.7 & 170.2 & \\
\hline
\end{tabular}

Tukey HSD (0.01): Variety $=3.65$; Irradiation dose $=8.36$; Variety $\times$ Irradiation dose $=13.23$.

Table 5. Effect of variety and irradiation dose on total soluble solids content ( ${ }^{\circ}$ Brix $)$.

\begin{tabular}{|c|c|c|c|c|c|c|c|}
\hline \multicolumn{8}{|c|}{ Total Soluble Solids ( ${ }^{\circ}$ Brix) } \\
\hline \multirow{2}{*}{ Variety } & \multicolumn{6}{|c|}{ Irradiation dose (Gy) } & \multirow{2}{*}{ Mean } \\
\hline & 0 & 200 & 400 & 600 & 800 & 1000 & \\
\hline Apantu & 13.0 & 12.5 & 12.3 & 12.8 & 13.3 & 13.3 & 12.8 \\
\hline Apem & 7.7 & 7.8 & 7.7 & 8.2 & 8.0 & 8.0 & 7.9 \\
\hline Mean & 10.3 & 10.1 & 10.0 & 10.6 & 10.6 & 10.7 & \\
\hline
\end{tabular}

Tukey HSD (0.01): Variety $=0.16$; Irradiation dose $=0.36$; Variety $\times$ Irradiation dose $=0.57$.

$(69.1 \mathrm{~g} / 100 \mathrm{~g})$ yet similar to the Apem irradiated at $800 \mathrm{~Gy}(69.8 \mathrm{~g} / 100 \mathrm{~g})$ (Table 6). The levels of starch found in the plantains in the present study, prior to irradiation, are consistent with values reported in literature [28] [29]. [30] working on Cavendish bananas found that the decrease in the degradation of starch correlated significantly with the increase in radiation dose. This is the case in this present study where higher doses of radiation resulted in quicker degradation of the starches. [31] [32] made a contrary assertion that doses below 0.75 $\mathrm{kGy}$ do not affect starch degradation whereas irradiation at $1.0 \mathrm{kGy}$ inhibits starch degradation of Prata bananas.

Starch reserves in fruits are an important factor in contributing to the sugar content in most ripe fruits [33]. In both the Apantu and Apem used in this work, the higher irradiation doses resulted in significantly more reducing sugars by stage 4 of the ripening process (Table 7). Irradiation has been reported to affect the rate of fructose and glucose formation during storage in Prata bananas. The rate of fructose and glucose formation is reported to be reduced with increasing radiation dose [31]. This present work is showing the opposite of the reported effect of irradiation on the fructose and glucose formation during ripening. The increase is due to the irradiation breaking down the starches into the simpler sugars.

\section{Conclusions}

Though some earlier reports on banana/plantain had suggested that irradiations doses of around $500 \mathrm{~Gy}$ could maintain green life for longer, this present work 
Table 6. Effect of variety and irradiation dose on starch content (g/100 g).

\begin{tabular}{cccccccc}
\hline \multirow{2}{*}{ Variety } & \multicolumn{5}{c}{ Irradiation dose (Gy) } & \multirow{2}{*}{ Mean } \\
\cline { 2 - 6 } & 0 & 200 & 400 & 600 & 800 & 1000 & \\
\hline Apantu & 80.9 & 81.1 & 80.5 & 80.1 & 79.1 & 73.9 & 79.3 \\
Apem & 71.1 & 70.7 & 76.1 & 71.0 & 69.8 & 69.1 & 71.3 \\
Mean & 76.0 & 75.9 & 78.3 & 75.6 & 74.5 & 71.5 & \\
\hline
\end{tabular}

Tukey HSD (0.01): Variety $=0.19$; Irradiation dose $=0.44$; Variety $\times$ Irradiation dose $=0.70$.

Table 7. Effect of variety and irradiation dose on sugar content (g/10 g).

\begin{tabular}{cccccccc}
\hline \multirow{2}{*}{ Variety } & \multicolumn{5}{c}{ Irradiation dose (Gy) } & Mean \\
\cline { 2 - 6 } & 0 & 200 & 400 & 600 & 800 & 1000 & \\
\hline Apantu & 2.13 & 2.11 & 2.09 & 2.18 & 2.25 & 2.35 & 2.19 \\
Apem & 1.84 & 1.87 & 1.87 & 1.87 & 1.89 & 1.90 & 1.87 \\
Mean & 1.98 & 1.99 & 1.98 & 2.03 & 2.07 & 2.13 & \\
\hline
\end{tabular}

Tukey HSD (0.01): Variety $=0.016 ;$ Irradiation dose $=0.037$; Variety $\times$ Irradiation dose $=0.059$.

has shown that doses of $200 \mathrm{~Gy}$ are equally effective. Carbon dioxide and ethylene production rates were affected by the gamma irradiation applied. The slower the release of ethylene by the plantain fruits, the longer it stayed in the green state prior to the onset of ripening. Irradiation caused the delay in ripening of the plantain fruits by affecting the respiratory rate more, than limiting the release of the ripening hormone, ethylene.

\section{Conflicts of Interest}

The authors declare no conflicts of interest regarding the publication of this paper.

\section{References}

[1] Lelievre, J.M., Latche, A., Jones, B., Bouzayem, M. and Pech, J.C. (1997) Ethylene and Fruit Ripening. Physiologia Plantarum, 101, 727-739.

https://doi.org/10.1111/j.1399-3054.1997.tb01057.x

[2] Etana, M.B. (2018) Review on the Effects of Ethylene (C2H4) on Quality of Fresh Fruit and Vegetable. The Case of Banana and Tomato. Basic Research Journal of Agricultural Science and Review, 6, 34-38.

[3] Liu, M., Pirrello, J., Chervin, C., Roustan, J.-P. and Bouzayen, M. (2015) Ethylene Control of Fruit Ripening: Revisiting the Complex Network of Transcriptional Regulation. Plant Physiology, 169, 2380-2390. https://doi.org/10.1104/pp.15.01361

[4] Barry, C.S. and Giovannoni, J.J. (2007) Ethylene and Fruit Ripening. Journal of Plant Growth Regulation, 26, 143-159. https://doi.org/10.1007/s00344-007-9002-y

[5] Pravendra, N., Trivedi, P., Sanr, A.P. and Sane, V.A. (2006) Role of Ethylene in Fruit Ripening. In: Khan, N.A., Ed., Ethylene Action in Plants, Springer-Verlog, Berlin Heidelberg, 178-224.

[6] Garcia-Salinas, C., Ramos-Parra, P.A. and de la Garza, R.D. (2016) Ethylene Treat- 
ment Induces Changes in Folate Profiles in Climacteric Fruit during Postharvest Ripening. Postharvest Biology and Technology, 118, 43-50.

https://doi.org/10.1016/j.postharvbio.2016.03.011

[7] Yang, S.F. (1987) The Role of Ethylene and Ethylene Synthesis in Fruit Ripening. In: Thompson, W.W., Nothnagel, E.A. and Huffaker, R.C., Eds., Plant Senescence: Its Biochemistry and Physiology, American Society of Plant Physiologists, Rockville, 156-166.

[8] Saltveit, M.E. (1993) Internal Carbon Dioxide and Ethylene Levels in Ripening Tomato Fruit Attached to or Detached from the Plant. Physiologia Plantarum, 89, 204-210. https://doi.org/10.1034/j.1399-3054.1993.890130.x

[9] Shellie, K.C. and Saltveit, M.E. (1993) The Lack of a Respiratory Rise in Muskmelon Fruit Ripening on the Plant Challenges the Definition of Climacteric Behaviour. Journal of Experimental Botany, 44, 1403-1406.

https://doi.org/10.1093/jxb/44.8.1403

[10] Pathak, N., Asif, M.H., Dhawan, P., Srivastava, M.K. and Nath, P. (2003) Expression and Activities of Ethylene Biosynthesis Enzymes during Ripening of Banana Fruits and Effect of 1-MCP Treatment. Plant Growth Regulation, 40, 11-19. https://doi.org/10.1023/A:1023040812205

[11] Bower, J., Holford, P., Latché, A. and Pech, J.-C. (2002) Culture Conditions and Detachment of the Fruit Influence the Effect of Ethylene on the Climateric Respiration of Melon. Postharvest Biology and Technology, 26, 135-146. https://doi.org/10.1016/S0925-5214(02)00007-8

[12] Liu, M., Diretto, G., Pirrello, J., Roustan, J.P., Li, Z., Giuliano, G., Regad, F. and Bouzayen, M. (2014) The Chimeric Repressor Version of an Ethylene Response Factor (ERF) Family Member, Sl-ERF.B3, Shows Contrasting Effects on Tomato Fruit Ripening. New Phytologist, 203, 206-218. https://doi.org/10.1111/nph.12771

[13] Lee, J.M., Joung, J.G., McQuinn, R., Chung, M.Y., Fei, Z., Tieman, D., Klee, H. and Giovannoni, J. (2012) Combined Transcriptome, Genetic Diversity and Metabolite Profiling in Tomato Fruit Reveals That the Ethylene Response Factor SIERF6 Plays an Important Role in Ripening and Carotenoid Accumulation. The Plant Journal, 70, 191-204. https://doi.org/10.1111/j.1365-313X.2011.04863.x

[14] United Fruit Sales Corporation (1975) Banana Ripening Guide. Boston.

[15] Zhu, M.C., Wang, S. and Lencki, R. (2001) Influence of Oxygen, Carbon Dioxide, and Degree of Cutting on the Respiration Rate of Rutabaga. Journal of Food Science, 66, 30-37. https://doi.org/10.1111/j.1365-2621.2001.tb15577.x

[16] Adao, R.C. and Gloria, M.B.A. (2005) Bioactive Amines and Carbohydrate Changes during Ripening of "Prata" Banana (Musa acuminate x M. balbisiana). Food Chemistry, 90, 705-711. https://doi.org/10.1016/j.foodchem.2004.05.020

[17] JCAM Japan Customs Analysis Methods (2001) Quantitative Analysis of Reducing Sugars in Sugar Preparations Consisting of Sugar and Dextrin. No. 114-R1.

[18] Dadzie, B.K. and Orchard, J.E. (1997) Routine Post-Harvest Screening of Banana/Plantain Hybrids: Criteria and Methods. INIBAP Technical Guidelines 2, International Plant Genetic Resources Institute, Montpellier, 75-85.

[19] Dionısio, A.P., Gomes, R.T. and Oetterer, M. (2009) Ionizing Radiation Effects on Food Vitamins: A Review. Brazilian Archives of Biology and Technology, 52, 1267-1278. https://doi.org/10.1590/S1516-89132009000500026

[20] Follett, P.A. and Weinert, E.D. (2009) Comparative Radiation Dose Mapping of Single Fruit Type and Mixed-Fruit Boxes for Export from Hawaii. Journal of Food Processing and Preservation, 33, 231-244. 
https://doi.org/10.1111/j.1745-4549.2008.00315.x

[21] Farkas, J. (2006) Irradiation for Better Foods. Trends in Food Science and Technology, 17, 148-152. https://doi.org/10.1016/j.tifs.2005.12.003

[22] Boynton, B.B., Welt, B.A., Sims, C.A., Brecht, J.K., Balaban, M.O. and Marshall, M.A. (2005) Effect of Low-Dose Electron Beam Irradiation on Respiration, Microbiology, Color and Texture of Fresh-Cut Cantaloupe. HortTechnology, 15, 802-807. https://doi.org/10.21273/HORTTECH.15.4.0802

[23] Barrera, V.J., Cayón, S.G. and Robles, G.J. (2009) Influencia de la exposición de las hojas y el epicarpio de frutos sobre el desarrollo y la calidad del racimo de plátano Hartón (Musa AAB Simmonds). Agronomia Colombiana, 27, 73-79.

[24] Arrieta, A., Baquero, U. and Barrera, J. (2006) Physico-Chemical Characterization of the Maturation Process Papocho Banana (Musa ABB Simmonds). Agronomía Colombiana, 24, 48-53.

[25] Mulagund, J., Porika, H., Soorianathasundaram, K. and Deepika, C. (2015) Influence of Growth Regulators Combined with Chemicals to Improve Post-Harvest Fruit Quality in Banana cv. Nendran (Musa AAB). Journal of Food Processing \& Technology, 6, 428. https://doi.org/10.4172/2157-7110.1000428

[26] Biale, J.B. (1960) Respiration of Fruits. In: Ruhland, W., Ed., Handbuch der. Pflanzenphysiologie, Vol. XII, Part 2, Springer, Berlin, 536-592.

[27] Ferris, R.S.B., Ortiz, R. and Vuylsteke, D. (1999) Fruit Quality Evaluation of Plantains, Plantain Hybrids, and Cooking Bananas. Postharvest Biology and Technology, 15, 73-81. https://doi.org/10.1016/S0925-5214(98)00067-2

[28] Annor, G.A., Asamoah Bonti, P. and Sakyi Dawson, E. (2016) Fruit Physical Characteristics, Proximate, Mineral and Starch Characterization of FHIA 19 and FHIA 20 Plantain and FHIA 03 Cooking Banana Hybrids. SpringerPlus, 5, 796. https://doi.org/10.1186/s40064-016-2465-1

[29] Marriott, J., Robinson, M. and Karikari, S.K. (1981) Starch and Sugar Transformation during the Ripening of Plantains and Bananas. Journal of the Science of Food and Agriculture, 32, 1021-1026. https://doi.org/10.1002/jsfa.2740321011

[30] Surendranathan, K.K. (2005) Post-Harvest Biotechnology of Fruits with Special Reference to Banana-Perspective and Scope. Indian Journal of Biotechnology, 4, 39-46.

[31] Gloria, M.B.A. and Adao, R.C. (2013) Effect of Gamma Radiation on the Ripening and Levels of Bioactive Amines in Bananas cv. Prata. Radiation Physics and Chemistry, 87, 97-103. https://doi.org/10.1016/j.radphyschem.2013.02.032

[32] Vieira, J.O. (1995) Efeitos da radiacao gama em banana Prata (Musa sp., grupo $\mathrm{AAB}$ ) irradiada em diferentes graus de maturidade e armazenada em condicao ambiente e em camara fria. PhD Thesis, USP, Piracicaba.

[33] Souleyre, E.J.F., Iannetta, P.P.M., Ross, H.A., Hancock, R.D., Shepherd, L.V.T., Taylor, R.V., Mark, A. and Davies, H.V. (2004) Starch Metabolism in Developing Strawberry. Plant Physiology, 121, 369-376.

https://doi.org/10.1111/j.0031-9317.2004.0338.x 